\title{
Workshop
}

\section{The Natives Are Restless: Proceedings from the ASHS Invasive Plants Research Interest Group 2017 and 2018 Workshops}

\author{
Lyn A. Gettys ${ }^{1}$ and Michael A. Schnelle ${ }^{2}$
}

ADDITIONAL INDEX wORDs. aggressive plants, invasion ecology, weeds

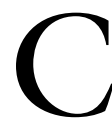
onventional wisdom suggests that only introduced species can be invasive and that indigenous species cannot be classified as "weeds" because they belong in their native range. Therefore, most weed ecology and management research is focused on non-native plants. It is becoming increasingly clear that some native plants have the ability to grow aggressively, outcompete other native species, and form dense monocultures, resulting

Received for publication 31 Jan. 2019. Accepted for publication 27 Mar. 2019.

Published online 8 August 2019.

${ }^{1}$ University of Florida IFAS Fort Lauderdale Research and Education Center, 3205 College Avenue, Davie, FL 33314

${ }^{2}$ Oklahoma State University, Department of Horticulture \& Landscape Architecture, 358 Agricultural Hall, Stillwater, OK 74078

We appreciate the support of the ASHS and of the presenters, authors, and attendees during both workshops.

This paper is an introduction to the Invasive Plants Research Professional Interest Group workshops "Strategies for Mitigating Invasiveness of Native Species," held on 30 Sept. 2017, in Waikoloa, HI, and "It's Native. Wait! It's Exotic...Oh No, It's a Nuisance!" held on 3 Aug. 2018, in Washington, DC.

L.A.G. is the corresponding author. E-mail: lgettys@ ufl.edu.

This is an open access article distributed under the CC BY-NC-ND license (https://creativecommons.org/ licenses/by-nc-nd/4.0/).

https://doi.org/10.21273/HORTTECH04288-19 cherry laurel (Prunus caroliniana), and K.W. Leonhardt talked about using induced sterility as a management strategy for invasive species. The goal of the 2018 workshop, titled "It's Native. Wait! It's Exotic...Oh No, It's a Nuisance!," was to discuss some of the factors that may result in nuisance natives, including loss of natural predators in a species' native range, invasive exotic haplotypes of native species, and how to manage ecosystems to preserve biodiversity and ecosystem function. Coordinator L.A. Gettys started the workshop by outlining the arguments against native status for waterlettuce (Pistia stratiotes), one of Florida's worst floating weeds. Then, M.A. Schnelle discussed a number of native plants that can escape cultivation and grow aggressively in areas where they are not wanted. A.K. Noyszewski spoke about the challenges of establishing the native compared to the exotic status of herbarium specimens of species with native and introduced biotypes and used reed canarygrass (Phalaris arundinacea) as a case study. The final speaker was N.O. Anderson, who argued that molecular biology may be necessary to distinguish between phenotypically identical native and exotic types of the same species of plants such as purple loosestrife (Lythrum salicaria) and reed canarygrass.

Attendees of these workshops gained valuable information and were provided with compelling evidence that aggressive growth and "invasiveness" are not solely the realm of introduced species. The concept that native plants can cause habitat destruction by reducing diversity is new and controversial, but this emerging phenomenon will certainly gain more attention in the future.

\section{Literature cited}

Marble, S.C. 2018. Native weedy pests of the Deep South. HortScience 53:12441249. 